\title{
PHYSICS OF REACTOR SAFETY
}

\author{
Quarterly Report \\ October-December 1980 \\ DO NOT MICROFILM \\ COVER
}

ARGONNE NATIONAL LABORATORY, ARGONNE, ILLINOIS Prepared for the U. S. NUCLEAR REGULATORY COMMISSION under Interagency Agreement DOE 40-550-75 


\section{DISCLAIMER}

This report was prepared as an account of work sponsored by an agency of the United States Government. Neither the United States Government nor any agency Thereof, nor any of their employees, makes any warranty, express or implied, or assumes any legal liability or responsibility for the accuracy, completeness, or usefulness of any information, apparatus, product, or process disclosed, or represents that its use would not infringe privately owned rights. Reference herein to any specific commercial product, process, or service by trade name, trademark, manufacturer, or otherwise does not necessarily constitute or imply its endorsement, recommendation, or favoring by the United States Government or any agency thereof. The views and opinions of authors expressed herein do not necessarily state or reflect those of the United States Government or any agency thereof. 


\section{DISCLAIMER}

Portions of this document may be illegible in electronic image products. Images are produced from the best available original document. 
The facilities of Argonne National Laboratory are owned by the United States Government. Under the terms of a contract (W-31-109-Eng-38) among the U. S. Department of Energy, Argonne Universities Association and The University of Chicago, the University employs the staff and operates the Laboratory in accordance with policies and programs formulated, approved and reviewed by the Association.

\section{MEMBERS OF ARGONNE UNIVERSITIES ASSOCIATION}

The University of Arizona

Carnegie-Mellon University

Case Western Reserve University

The University of Chicago

University of Cincinnati

Illinois Institute of Technology

University of Illinois

Indiana University

The University of Iowa

Iowa State University
The University of Kansas

Kansas State University

Loyola University of Chicago

Marquette University

The University of Michigan

Michigan State University

University of Minnesota

University of Missouri

Northwestern University

University of Notre Dame
The Ohio State University

Ohio University

The Pennsylvania State University

Purdue University

Saint Louis University

Southern Illinois University

The University of Texas at Austin

Washington University

Wayne State University

The University of Wisconsin-Madison

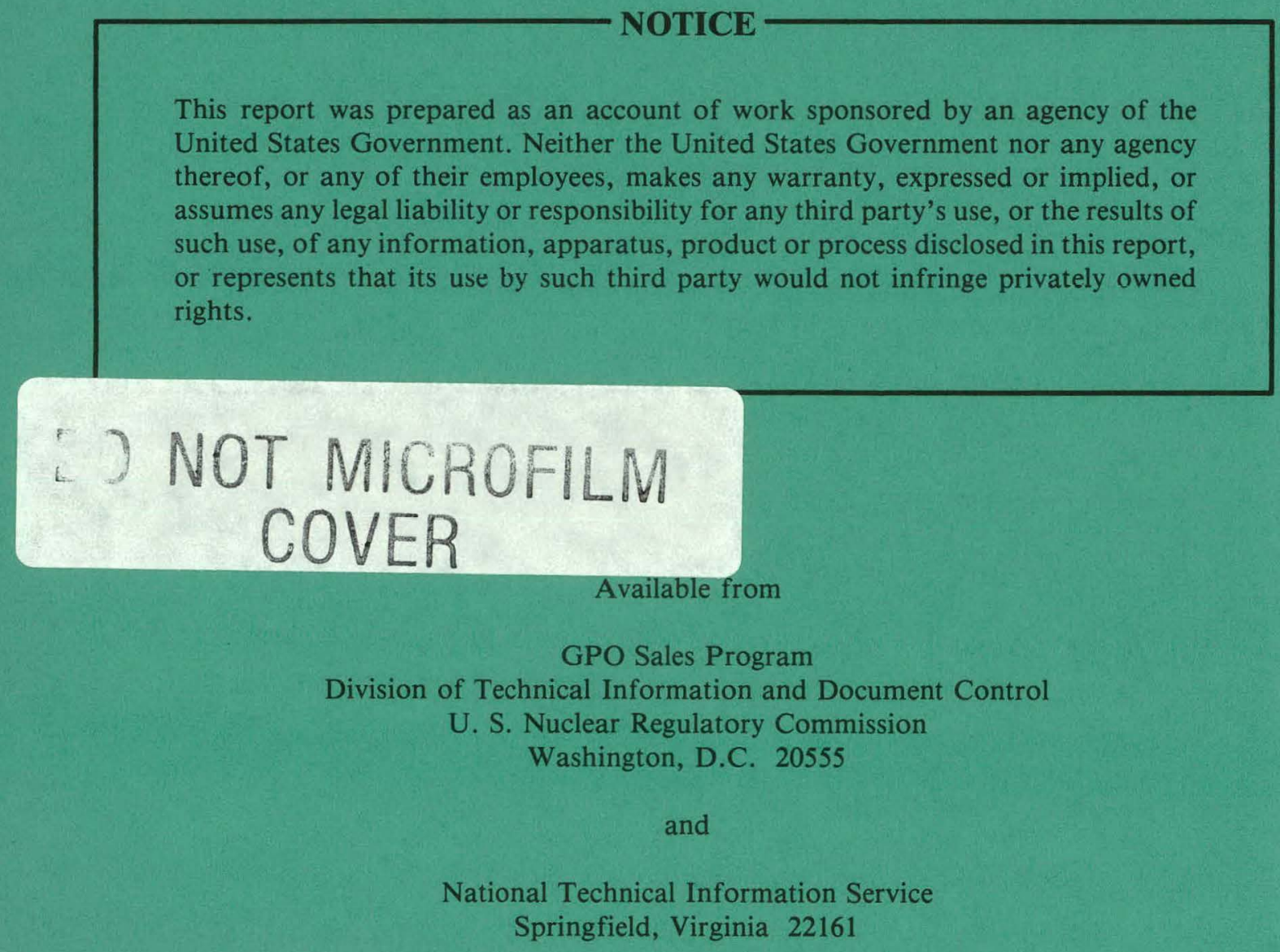




\section{DISCLAIMER}

This report was prepared as an account of work sponsored by an agency of the United States Government. Neither the United States Government nor any agency thereof, nor any of their employees, makes any warranty, express or implied, or assumes any legal liability or responsibility for the accuracy, completeness, or usefulness of any information, apparatus, product, or process disclosed, or represents that its use would not infringe privately owned rights. Reference herein to any specific commercial product, process, or service by trade name, trademark, manufacturer, or otherwise does not necessarily constitute or imply its endorsement, recommendation, or favoring by the United States Government or any agency thereof. The views and opinions of authors expressed herein do not necessarily state or reflect those of the United States Government or any agency thereof.

NUREG/CR-1526 Vol. IV ANL-80-54 Vol. IV

(Distribution Code: R7)
ARGONNE NATIONAL LABORATORY

9700 South Cass Avenue Argonne, Illinois 60439

PHYSICS OF REACTOR SAFETY

Quarterly Report

October-December 1980

\author{
Applied Physics Division \\ Components Technology Division
}

February 1981
NUREG/CR--1526-Vo1 . 4

TI86 002750

\author{
ANL $-80-25$ \\ ANL-80-54 (I) \\ ANL-80-54 (II) \\ ANL-80-54 (III)
}

$\begin{array}{rr}\text { October-December } & 1979 \\ \text { January-March } & 1980 \\ \text { April-June } & 1980 \\ \text { July-September } & 1980\end{array}$

\footnotetext{
Prepared for the Division of Reactor Safety Research Office of Nuclear Regulatory Research

U. S. Nuclear Regulatory Commission Washington, D. C. 20555

Under Interagency Agreement DOE 40-550-75
}

NRC FIN Nos. A2015 and A2045 


\author{
PHYSICS OF REACTOR SAFETY \\ Quarterly Report \\ October-December 1980
}

\begin{abstract}
This Quarterly progress report summarizes work done during the months of October-December 1980 in Argonne National Laboratory's Applied Physics and Components Technology Divisions for the Division of Reactor Safety Research of the U.S. Nuclear Regulatory Commission. The work in the Applied Physics Division includes reports on reactor safety modeling and assessment by members of the Reactor Safety Appraisals Section. Work on reactor core thermal-hydraulics is performed in ANL's Components Technology Division, emphasizing 3-dimensional code development for LMFBR accidents under natural convection conditions. An executive summary is provided including a statement of the findings and recommendations of the report.
\end{abstract}

FIN No.

A2015

A2045
4

$\underline{\text { Title }}$

Reactor Safety Modeling and Assessment 3-D Time-dependent Code Development 
EXE CUTIVE SUMMARY. . . . . . . . . . . . . . . . . . . . 1

I. REACTOR SAFETY MODELING AND ASSESSMENT

A. BIflo Benchmark Activities . . . . . . . . . . . . . 2

B. Calculation of Effect of Creep on Fission . . . . . . . . 2 Gas Release in NEFIG

II. THREE-DIMENSIONAL CODE DEVELOPMENT FOR CORE THERMAL-HYDRAULIC ANALYSIS OF LMFBR ACCIDENTS UNDER NATURAL CONVECTION CONDITIONS

A. Introduction .................... 6

B. COMMIX-2, Two-Phase Code Development. . . . . . . . . . 6

1. German Seven-Pin Hexagonal Fuel Assembly . . . . . . . . 6

2. Analysis of 31-Pin Fuel Assembly using Two-Fluid Model • • • 7

3. Analysis of THORS wire wrapped 19-Pin Bundle 6A . . . . . . 7

C. Development of BODYFIT-1FE . . . . . . . . . . . . 8 REFERENCES . . . . . . . . . . . . . . . . . . . 13 
1. Axial and Transverse Partitioning of the Model 7-Pin Bundle .. . . 9

2. Flow Rundown Transient . . . . . . . . . . . . . 10

3. Transient Axial Limits of Dispersed Sodium Vapor . . . . . . . . 10

4. Comparison of the Axial Temperature Distribution . . . . . . . . 11

5. Comparison of Boiling Region in THORS Bundle 3C . . . . . . . . . Il

6. Comparison of the Axtal Temperature Distribution at the Center . . . 12

7. Comparison of the Radial Temperature Distribution at the End of the Heated Section . . . . . . . . . . . . . 12

LIST OF TABLES

$\underline{\text { Page }}$

I. Time - Temperature Dates in Transient Fission Gas

Release and Swelling Calculation ............... . 3

II. Summary of Results for Effect of Creep on Fission

Gas Release and Fuel Swelling . . . . . . . . . . . . . 4 


\section{EXECUTIVE SUMMARY}

A report describing the physical modeling and numerical methodology currently incorporated in BIFLO was prepared and will be issued as an internal report in the near future.

Problems arising from trying to use the COMMIX code for a 19-pin wirewrapped bundle in connection with BIFLO are being resolved in cooperation with the code developers. COMMIX is being used for analysis of THORS steady-state experiments.

The effect of fuel creep on gas release from fuel grains when using the NEFIG code was studied using modeling proposed by $R$. Ostensen and adapted by D. Worledge. It was found that the effect was noticeable for slow transients', but. insignificant for fast transients and is sensitive to the fuel hydrostatic pressure.

In the development work of the COMMIX codes, all efforts this quarter were devoted to the two-phase COMMIX-2 code. The following three problems were analyzed using COMMIX-2.

(i) German Seven Pin Hexagonal Fuel Assembly, Analysis \#2: This is the analysis of the second flow rundown transient experiment in a test section with seven electrically heated rods arranged in a hexagonal array.

(ii). Analysis of 31 Pin Fuel Assembly using Two-Fluid Model: This analysis was carried out using the two-fluid model in COMMIX-2. The two-fluid-model results are compared with the previously obtained homogeneous model results.

(iii) THORS wire-wrapped 19 Pin Bundle 6A: This analysis was carried out to determine the effects of wire wrap on fluid flow and heat transfer.

Simultaneously, efforts were also devoted to (i) preparing the user's manual, (ii) reducing the computer storage requirements, (iii) developing subroutines for mapping of. the heat transfer. flow regimes and, (iv) improving the solution sequence.

In the area of BODYFIT code development, work has been initiated to incorporate the homogeneous two-phase flow model in the code. Several modifications were made in the area of input preparation and fluid properties for the purpose of clarity and efficiency. The BODYFIT-1FE document is in its final stage of being typed and corrected. 
I. REACTOR SAFETY MODELING AND ASSESSMENT

(A2015)

\section{A. BIFLO Benchmarking Activities ( $P$. L. Garner)}

Efforts were continued to use pre-release versions of the COMMIX-2 computer code which is being developed in the Components Technology (CT) Division at ANL. Several new code versions were tried, each version requiring modification to the code access procedures, COMMON blocks, and input data. The problems found while trying to execute the code for a 19-pin wire-wrapped bundle are being resolved in close cooperation with the code developers in CT.

Several additional calculations of steady-state non-boiling tests'performed in THORS Bundle-6A (Ref. 1) in which only a single off-center rod was heated have been performed using the COMMIX-1 computer code ${ }^{2}$ to continue the study of coolant mixing and the impact of the duct wall for this test geometry.

The program that plots the thermocouple data from the THORS Bundle-6A transient tests ${ }^{3}$ as a function of radial position and time for selected axial levels has been modified to plot the data, optionally, as a function of radial and axial position at selected times to aid in the interpretation of the transient boiling tests. The various uncertainties in the experiment data are being examined with respect to their impact on analysis of the transient tests with the BIFLO and COMMIX-2 computer codes. Calculations of a transient boiling test (Test 73E/Run 102A in THORS Bundle 6A) using BIFLO have continued to address the proper modeling of thermal and hydraulic boundary conditions for simulation of the test.

B. Calculation of Effect of Creep on Fission Gas Release in NEFIG (H. Humme1)

R. Ostensen incorporated in the FISGAS code 4 a mechanism for fission gas bubble growth by power-law fuel creep. D. Worledge ${ }^{5}$ adapted this model for inclusion in his version of the NEFIG mode $1^{6}$ applied to the problem of fuel fragmentation by rapid heating. In this model a shell of solid fuel is assumed to surround each fission gas bubble contained within the fuel grains with the shell thickness determined by the volume of fuel per bubble. In Ostensen's model this shell is cylindrical, while Worledge uses spherical geometry. The fuel shell creeps under the effective differential stress across it, which depends on the excess of the bubble internal pressure over the surface tension constraint and the exernal hydrodynamic pressure. The creep rate is assumed to be equal to the stress raised to a specified power times a temperature-dependent constant. Note that gas bubbles on grain boundaries and edges are not considered here.

It was of interest to see whether or not creep effects could have a significant effect on fission gas release. Insertion of Worledge's expression for creep rate in our version of NEFIG shows that for transients with fuel heating rate $100-200 \mathrm{~K} / \mathrm{sec}$ there is a significant effect of creep on bubble growth. This causes a large increase in fuel swelling and a somewhat smaller but still significant decrease in gas release from the fuel grains because of the larger bubble size. Worledge does not consider the effect of hydrostatic pressure in Ref. 5. DiMelfi $i^{7}$ has given the solution for the case of pressure 
applied to the exterior of the fuel sphere surrounding the bubble.' This solution shows that the effect of the exterior pressure is to reduce the bubble excess pressure by the'exterior pressure. (Note that $\dot{\varepsilon}_{1}$ as defined by DiMelfi in his Eq. 12 should be $\frac{\dot{\mathrm{V}}_{\mathrm{o}}}{3 \mathrm{~V}_{\mathrm{o}}}$ ). Use of this solution is a crude way to take account of hydrostatic pressure in the fuel, but setting this pressure equal to the gas pressure in the pin void space should give. a lower bound for the effect of hydrostatic pressure.

Calculations of the effect of fuel creep on fission gas release from fuel grains and on intragranular swelling have been carried out for three power transients, two of which correspond to a relatively slow TOP with fuel heating rate in the range $100-200 \mathrm{~K} / \mathrm{sec}$ and a more rapid one corresponding to LOF-TOP conditions, with fuel heating rate reaching $5000-10,000 \mathrm{~K} / \mathrm{sec}$. One of the slower transients is based on the HEDL FGR-39 test ${ }^{8}$, while the other is based on SAS3D calculations for unrestructured fuel in a lower-power channel for the $10 \notin / \mathrm{sec}$ TOP case of the WAC Comparative Studies. 9 The more rapid transient is one used previously in parametric studies of fission gas release, and is denoted as "Curve 2" in ANL-75-67, p. 3,10 with $\nabla \mathrm{T}=10^{4}$ and $\mathrm{C}_{\mathrm{O}}=2.0 \times 10^{20}$ atoms gas $/ \mathrm{cm}^{3}$. These time-temperature curves are shown in Table $I$. Also

TABLE I. Time - Temperature Dates in Transient Fission Cas Releasc and Swelling Calculation

\begin{tabular}{|c|c|c|}
\hline $\begin{array}{c}\text { FGR }-39 \text { (HEDL) } \\
C_{0}=1.56 \times 10^{20} \text { atoms } / \mathrm{cm}^{3} \\
D^{a}=38.0 \mu \mathrm{mt}\end{array}$ & $\begin{array}{c}\text { WAC TOP } \\
C_{o}=1.33 \times 10^{20} \text { atoms } / \mathrm{cm}^{3} \\
D=20.1 \mu \mathrm{m}\end{array}$ & $\begin{aligned} C_{0}=2.00 \times 10^{20} \text { atoms } / \mathrm{cm}^{3} \\
D=16.6 \mathrm{\mu m} \\
V T=10^{4} \mathrm{k} / \mathrm{cm}\end{aligned}$ \\
\hline
\end{tabular}

\begin{tabular}{|c|c|c|c|c|c|c|c|}
\hline $\begin{array}{l}\text { Time, } \\
\text { Sec. } \\
\end{array}$ & $\mathrm{T}, \mathrm{K}$ & $\begin{array}{r}\nabla \mathrm{T}, \\
\mathrm{K} / \mathrm{cm} \\
\end{array}$ & $\begin{array}{l}\text { Time, } \\
\text { Sec. }\end{array}$ & $\underline{T, K}$ & $\begin{array}{r}\nabla \mathrm{T}, \\
\mathrm{K} / \mathrm{cm} \\
\end{array}$ & $\begin{array}{l}\text { Time, } \\
\text { Sec. }\end{array}$ & $\underline{T, K}$ \\
\hline 3.00 & 1652 & 1567 & 1.72 & 2082 & 5501 & 0.20 & 1830 \\
\hline 4.00 & 1753 & 2128 & 3.49 & 2308 & 5744 & 0.40 & 1895 \\
\hline 5.00 & 1905 & 3404 & 4.61 & 2.467 & 5714 & 0.60 & . 1998 \\
\hline 6.00 & 2033 & 3482 & 5.66 & 2629 & 5584 & 0.70 & - 2058 \\
\hline 7.00 & 2197 & 4294 & 6.51 & 2763 & 5480 & 0.80 & 2133 \\
\hline 8.00 & 2384 & 5145 & 7.41 & 2898 & 5178 & 0.90 & 2224 \\
\hline 9.00 & 2567 & 5242 & 8.23 & 2980 & 4405 & 1.00 & 2333 \\
\hline 10.00 & 2801 & 6267 & & & & 1.05 & 2403 \\
\hline 11.00 & 2951 & 4156 & & & & 1.10 & 2518 \\
\hline \multirow[t]{4}{*}{12.00} & 3000 & 4217 & & & & 1.13 & 2623 \\
\hline & & & & & & 1.16 & 2733 \\
\hline & . & & & & & 1.18 & 2973 \\
\hline & & & . & & & 1.19 & 3040 \\
\hline
\end{tabular}

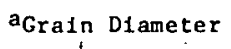

given are the temperature gradients and the grain diameter, D. Results are given in Table II for the later parts of the transients. These results show that very large fuel swelling is predicted for the FGR-39 case at low hydrostatic pressure as the melting point is approached. There is an associated considerable decrease in gas release because of the increased bubble size and resultant lower bubble velocity. The swelling is greatly reduced if a hydrostatic pressure of 150 atms. is assumed. This pressure is in the range that, will typically cause fallure for hot clad. The associated effect on gas release is also considerably reduced. 
TABLE II. Summary of Results for Effect of Creep on Fission Gas Release and Fuel Swelling

\begin{tabular}{|c|c|c|c|c|c|c|c|c|c|c|c|c|c|c|c|c|c|}
\hline \multirow{2}{*}{$\begin{array}{l}\underset{\text { Atm }}{\text { PRESSa }} \\
\end{array}$} & \multicolumn{5}{|c|}{ FGR - 39} & \multicolumn{6}{|c|}{ WAC TOP } & \multicolumn{2}{|c|}{ - } & \multicolumn{2}{|c|}{ Curve 2} & \multirow[b]{2}{*}{$\begin{array}{l}\text { SWEL } \\
(\%)\end{array}$} & \multirow[b]{2}{*}{$\mathrm{RB}, \mathrm{nm}$} \\
\hline & Creep & $\begin{array}{l}\text { Time, } \\
\text { Sec. }\end{array}$ & FREL $b$ & $\begin{array}{l}\text { SWELC } \\
(\%)\end{array}$ & $\mathrm{RB}^{\mathrm{d}}, \mathrm{nm}$ & $\begin{array}{l}\text { PRESS, } \\
\text { At回 }\end{array}$ & Creep & $\begin{array}{l}\text { Time, } \\
\text { Sec. }\end{array}$ & FREL & $\begin{array}{l}\text { SWEL } \\
(\%)\end{array}$ & $\mathrm{RB}, \mathrm{m}$ & $\begin{array}{c}\text { PRESS, } \\
\text { Atm }\end{array}$ & Creep & $\begin{array}{l}\text { Time, } \\
\text { Sec. }\end{array}$ & FREL & & \\
\hline 1.0 & no & $\begin{array}{l}10.0 \\
11.0 \\
12.0\end{array}$ & $\begin{array}{l}0.297 \\
0.452 \\
0.562\end{array}$ & $\begin{array}{l}3.6 \\
4.1 \\
4.2\end{array}$ & $\begin{array}{l}162 \\
324 \\
493\end{array}$ & 2.5 & no & $\begin{array}{l}6.51 \\
7.41 \\
8.23\end{array}$ & $\begin{array}{l}0.585 \\
0.749 \\
0.866\end{array}$ & $\begin{array}{l}2.5 \\
2.0 \\
1.4\end{array}$ & $\begin{array}{l}183 \\
306 \\
447\end{array}$ & 2.5 & no & $\begin{array}{l}1.13 \\
1.16 \\
1.18 \\
1.19\end{array}$ & $\begin{array}{l}0.155 \\
0.200 \\
0.251 \\
0.279\end{array}$ & $\begin{array}{l}2.8 \\
3.1 \\
3.4 \\
3.6\end{array}$ & $\begin{array}{l}33.5 \\
44.3 \\
61.0 \\
68.6\end{array}$ \\
\hline 1.0 & yes & $\begin{array}{l}10.0 \\
11.0 \\
12.0\end{array}$ & $\begin{array}{l}0.270 \\
0.360 \\
0.408\end{array}$ & $\begin{array}{r}9.4 \\
27.8 \\
51.2\end{array}$ & $\begin{array}{l}237 \\
701 \\
1336\end{array}$ & 2.5 & yes & $\begin{array}{l}6.51 \\
7.41 \\
8.23\end{array}$ & $\begin{array}{l}0.566 \\
0.695 \\
0.778\end{array}$ & $\begin{array}{l}4.1 \\
6.2 \\
7.8 \\
\end{array}$ & $\begin{array}{l}220 \\
453 \\
776\end{array}$ & 2.5 & yes & $\begin{array}{l}1.13 \\
1.16 \\
1.18\end{array}$ & $\begin{array}{l}0.154 \\
0.196 \\
0.240\end{array}$ & $\begin{array}{l}3.1 \\
4.3 \\
9.4\end{array}$ & $\begin{array}{l}34.8 \\
50.3 \\
90.0\end{array}$ \\
\hline 150 & no & $\begin{array}{l}10.0 \\
11.0 \\
12.0\end{array}$ & $\begin{array}{l}0.300 \\
0.458 \\
0.569\end{array}$ & $\begin{array}{l}3.5 \\
3.9 \\
3.9\end{array}$ & $\begin{array}{l}159 \\
316 \\
477\end{array}$ & 150 & no & $\begin{array}{l}6.51 \\
7.41 \\
8.23\end{array}$ & $\begin{array}{l}0.591 \\
0.759 \\
0.876\end{array}$ & $\begin{array}{l}2.3 \\
1.8 \\
1.1\end{array}$ & $\begin{array}{l}178 \\
296 \\
430\end{array}$ & 150 & no & $\begin{array}{l}1.19 \\
1.13 \\
1.16\end{array}$ & $\begin{array}{l}0.255 \\
0.155 \\
0.200\end{array}$ & $\begin{array}{l}12.6 \\
2.8 \\
3.0\end{array}$ & $\begin{array}{l}112 \\
33.4 \\
44.0\end{array}$ \\
\hline \multirow[t]{2}{*}{150} & yes & $\begin{array}{l}10.0 \\
11.0 \\
12.0\end{array}$ & $\begin{array}{l}0.277 \\
0.384 \\
0.455\end{array}$ & $\begin{array}{l}7.3 \\
12.9 \\
14.1\end{array}$ & $\begin{array}{l}215 \\
516 \\
807\end{array}$ & 150 & yes & $\begin{array}{l}6.51 \\
7.41 \\
8.23\end{array}$ & $\begin{array}{l}0.577 \\
0.719 \\
0.817\end{array}$ & $\begin{array}{l}3.3 \\
3.8 \\
3.4\end{array}$ & $\begin{array}{l}204 \\
38.1 \\
587\end{array}$ & & & $\begin{array}{l}1.18 \\
1.19\end{array}$ & $\begin{array}{l}0.257 \\
0.280\end{array}$ & $\begin{array}{l}3.4 \\
3.5\end{array}$ & $\begin{array}{l}60.5 \\
68.0\end{array}$ \\
\hline & & & & & & & & & & . & . & 150 & yes & $\begin{array}{l}1.13 \\
1.16 \\
1.18 \\
1.19\end{array}$ & $\begin{array}{l}0.155 \\
0.197 \\
0.243 \\
0.258\end{array}$ & $\begin{array}{l}3.0 \\
4.1 \\
7.9 \\
9.8\end{array}$ & $\begin{array}{r}34.5 \\
49.2 \\
84.0 \\
102\end{array}$ \\
\hline
\end{tabular}

aHydrostatic pressure

bractional fission gas release from grains

CIntragranular fuel swelling

dintragranular fission gas bubble radius 
The calculated swelling is considerably less for the WAC TOP case than for FGR-39. This seemed puzzling at first because of the similar timetemperature variation as the fuel melting point is approached. However, the grain size assumed in this case was considerably smaller, leading to a higher gas release, and it was determined by parametric variation that this was the main cause of the difference in swelling. Also, the relatively small differences in temperature over the later parts of the two transients turned out to have a significant effect because of the rapid variation in assumed creep rate with temperature near the melting point. This whole calculation is rather speculative because of the uncertainties involved, particularly in high temperature creep data. ${ }^{4}$ The FD1 experiments showed fuel swelling in restructured fuel, where the fission gas content is small, and none in the unrestructured fuel 1 , where NEFIG assumes swelling takes place.

For the Curve 2 case the calculated fuel swelling is significant even on the short time scale assumed, because of the high fractional gas retention and higher final temperature assumed in the calculation. However, the gas release is not significantly affected by creep effects.

In summary, creep effects do appear to have a noticeable effect on fission gas release for slower transients, and are probably worth taking into account on a parametric basis. These effects are reduced when the hydrostatic pressure present in the pin when failure conditions are approached is taken into account, and become insignificant for very rapid transients. 
II. THREE-DIMENSIONAL CODE DEVELOPMENT FOR

CORE THERMAL-HYDRAULIC ANALYSIS OF

LMFBR ACCIDENTS UNDER NATURAL CONVECTION CONDITIONS

A2045

A. Introduction

The objective of this program is to develop computer programs (COMMIX and BODYFIT) which can be used for either single-phase or two-phase thermalhydraulic analysis of reactor components under normal and off-normal operating conditions. The governing equations of conservation of mass, momentum, and energy are solved as a boundary value problem in space and an initial value problem in time.

COMMIX is a three-dimensional, transient, compressible flow computer code for reactor thermal-hydraulic analysis. It is a component code and uses a porous medium formulation. The concept of volume porosity, surface permeability, and distributed resistance and heat source (or sink) is employed in the COMMIX code for quasi-continuum (or rod-bundle) thermal-hydraulic analysis. It provides a greater range of applicability and an improved accuracy than subchannel analysis. By setting volume porusity and surface permeability equal to unity, and resistance equal to zero, the COMMIX code can equally handle continuum problems (reactor inlet or outlet plenum, etc.).

BODYFIT is a three-dimensional, transient, compressible flow computer code for reactor rod bundle thermal-hydraulic analysis. This is also a component code, and it uses a boundary-fitted coordinate transformation. The complex rod bundle geometry is transformed into either rectangular or cylindrical coordinates with uniform mesh. Thus, the physical boundaries, including each rod, coincide with computational grids. This allows the NavierStokes equatlons, Logelter with the boundary conditions, to be represented accurately in the finite-difference formulation. Thus, the region in the immediate vicinity of solid surfaces, which is generally dominant in determining the character of the flow, can be accurately resolved.

During this quarter all efforts were devoted to the development of the COMMIX-2 (3-D, two-phase) computer code and the BODYFIT-1 code.

B. COMMIX-2, Two-Phase Code Development (H. M. Domanus, C. C. Miao, W. T. Sha and V. L. Shah)

During this quarter, the following three problems were analyzed with COMMIX-2.

1. German Seven-Pin Hexagonal Fuel Assembly [12]

The model seven-pin bundle is shown in Fig. 1. The model consists of a 1.40 meter overall length which consists of a 0.20 meter entrance region, followed by a 0.60 meter heated region, and a 0.60 meter exit region. The seven electrically heated pins have an outside diameter of 0.006 meter and are arranged in a 0.0079 meter triangular pitch within a hexagonal duct as shown. The pins are heated uniformly, both from pin-to-pin and over the heated length. The duct walls are 0.05 meter thick. The corresponding position of the thermocouple measurements are shown in Fig. 1. 
The simulation consists of first obtaining a steady-state solution, then imposing the specified velocity transient. The sodium coolant enters the bundle uniformly at the bottom with a temperature of $562^{\circ} \mathrm{C}$ and a velocity of 2.97 meter/second. As the sodium coolant flows up the bundle, a total of $11.40 \mathrm{~kW}$ of heat is generated within the seven electric heaters.

The normalized flow transient is shown in Fig. 2. As the flow decreases, the temperatures in the fuel assembly increase. The resulting temperature transients compare favorably with the experimental data and previous COMMIX-1A single-phase calculations. ${ }^{13}$ It is worth noting that the simulation of the steady-state and transient up to the inception of boiling required much less computer time than the previous COMMIX-1A simulation. This was due primarily to the fully implicit formulations of COMMIX-2 which permitted a time step size much larger than the Courant condition.

As the temperatures rise, the saturation temperature is reached and boiling starts. As the boiling continues and more vapor is produced, the vapor is convected downstream of the heated section, and a boiling region is formed. Fig. 3 shows the axial limits of the transient boiling region. While the calculation shows the boiling region to be three-dimensional, the results shown are a projection of the boiling region on the axial length of the test section. This comparison with the experimental data is favorable.

2. Analysis of $31-P$ in Fuel Assembly using Two-Fluid Model:

This is the analysis of the boiling test (Test 20; Run \#104) with bundle $3 \mathrm{C}$ in the Liquid Metal Fast Breeder Reactor (LMFBR) Thermal-Hydraulic Out of Reactor Safety (THORS) Facility. Bundle 3C has 19 pins in the center, arranged in a hexagonal array and 12 pins in the surrounding annular region. All pins are electrically heated to simulate fuel pins. The heating section is $533 \mathrm{~mm}$ long and has a blockage plate at axial position $\mathrm{Z}=381 \mathrm{~mm}$. The flow transient was presented in the last quarterly report.

Results have been obtained with COMMIX-2 using two-fluid model for initial and final steady state conditions. Figures 4 and 5 show the comparison of axial temperature distribution and the spread of the boiling region respectively for the final steady state condition. We can see that the COMMIX-2 predictions, obtained with two-fluid model, are in close agreement with the measurements.

\section{Analysis of THORS wire wraped 19-Pin Bundle 6A}

In order to determine the effect of wire-wrap, the analysis of the sodium test data 23, run 101 for THORS wire wrapped 19-pin bundle 6A, was carried out. The initial steady state solution was obtained with COMMIX-2, first without using the wire wrap model, and then with the wire wrap model. Figures 6 and 7 show the comparison of the predicted axial and radial temperature distributions with the experimental measurements. We can see that the results obtained with the wire wrap model are in closer agreement with the experimental measurements. 
Other Development Work

(1) A significant amount of time and effort was spent this quarter in cleaning up the code, in documentation, and in preparation of a users manual. A preliminary version of the code documentation will be ready for release in the very near future.

(2) Several modifications were incorporated to reduce the computer storage requirement. Initially, a 19-pin hexagonal fuel assembly single-phase problem with 24 axial levels and 2248 cells required storage over $2000 \mathrm{~K}$. With the modifications now incorporated, the same problem requires $\sim 1500 \mathrm{~K}$ of computer storage. Efforts are being continued to further improve the storage requirement.

(3) The subroutines for mapping the heat transfer flow regime and for evaluation of the corresponding surface heat transfer coefficients have been developed. The modifications required in the code for incorporating these subroutines have been made.

(4) Two additional subroutines have been developed and incorporated in the code to permit SOK solution option for the solution of energy and continuity (fluid-volume fraction) equations. We are now testing these subroutines.

(5) Some effort and time was devoted to experimenting with different solution sequences. Further experimentation is planned to determine an optimum.

C. Development of BODYFIT-1FE (B. C-J. Chen and W. T. Sha)

Some modifications and improvements were performed for BODYFIT-1FE during this quarter. These changes were done mainly for the purpose of clarlty and efficiency. They are mostly in the area of input preparations and fluid properties. These changes reflect the feedback from users at the Massachusetts Institute of Technology. They are currently using the code to perform some thermal-hydraulic analysis of square rod bundles in order to compare with their experimental data. We have provided a great deal of user support and consultation to them during this quarter. A preliminary version of the code is ready for release.

Incorporation of a homogeneous two-phase flow model into the code was also investigated during this quarter. It was estimated that two to three man-months of effort will be needed for the implementation of the model. However, incorporation of this model will considerably extend the capability of the code for rod bundle thermal-hydraulic analysis. Currently, we are surveying various two-phase physical models and heat transfer correlations in the open literature.

The BODYFIT-IFE document is in its final stage of being typed and corrected. It includes both the theory and the application of the technique of boundary-fitted coordinate systems. A users manual is included as a part of the report as well. The report should be printed during the next quarter. 


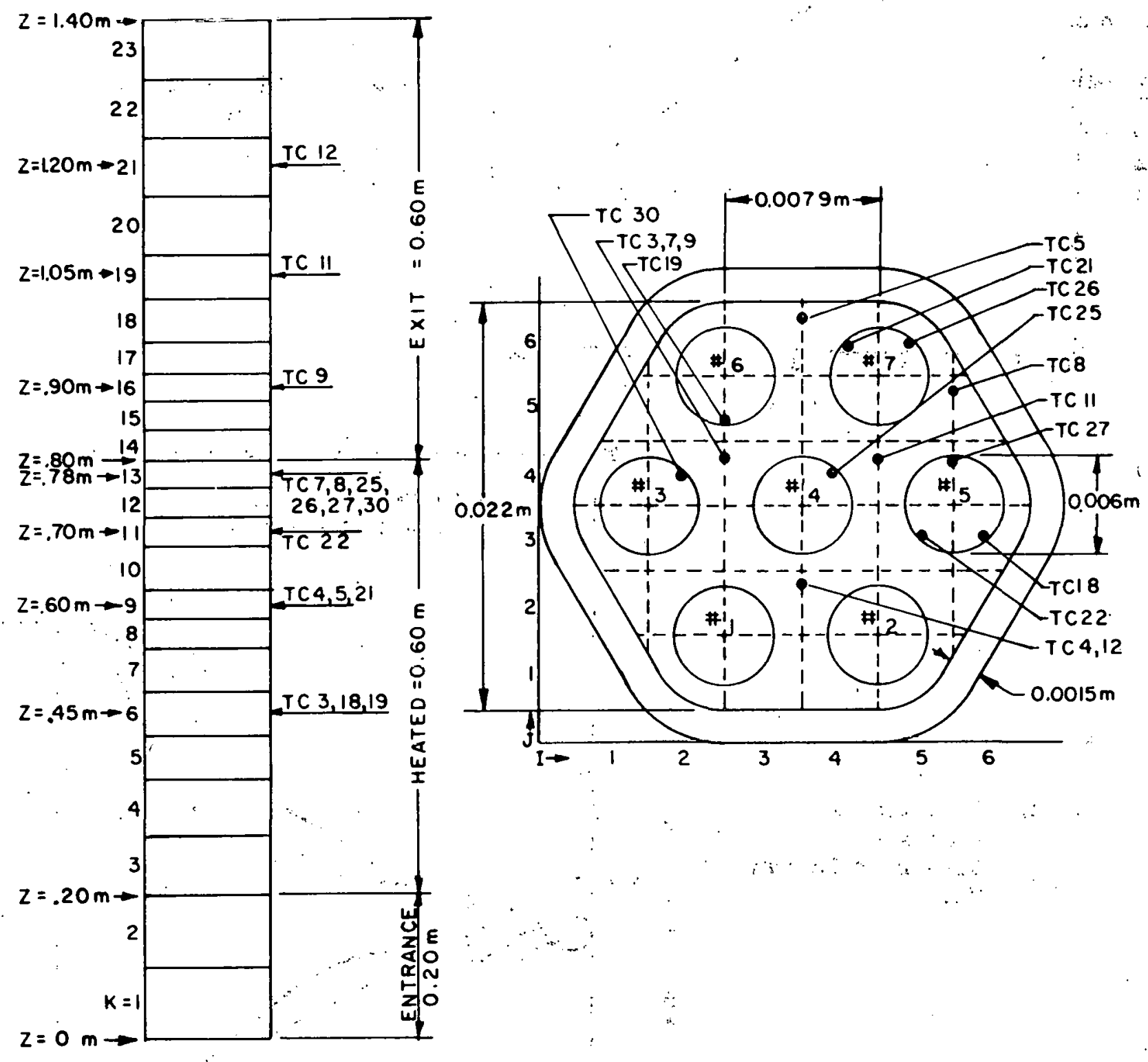

Fig. 1. Axial and Transverse Partitioning of the Model 7-Pin Bundle 


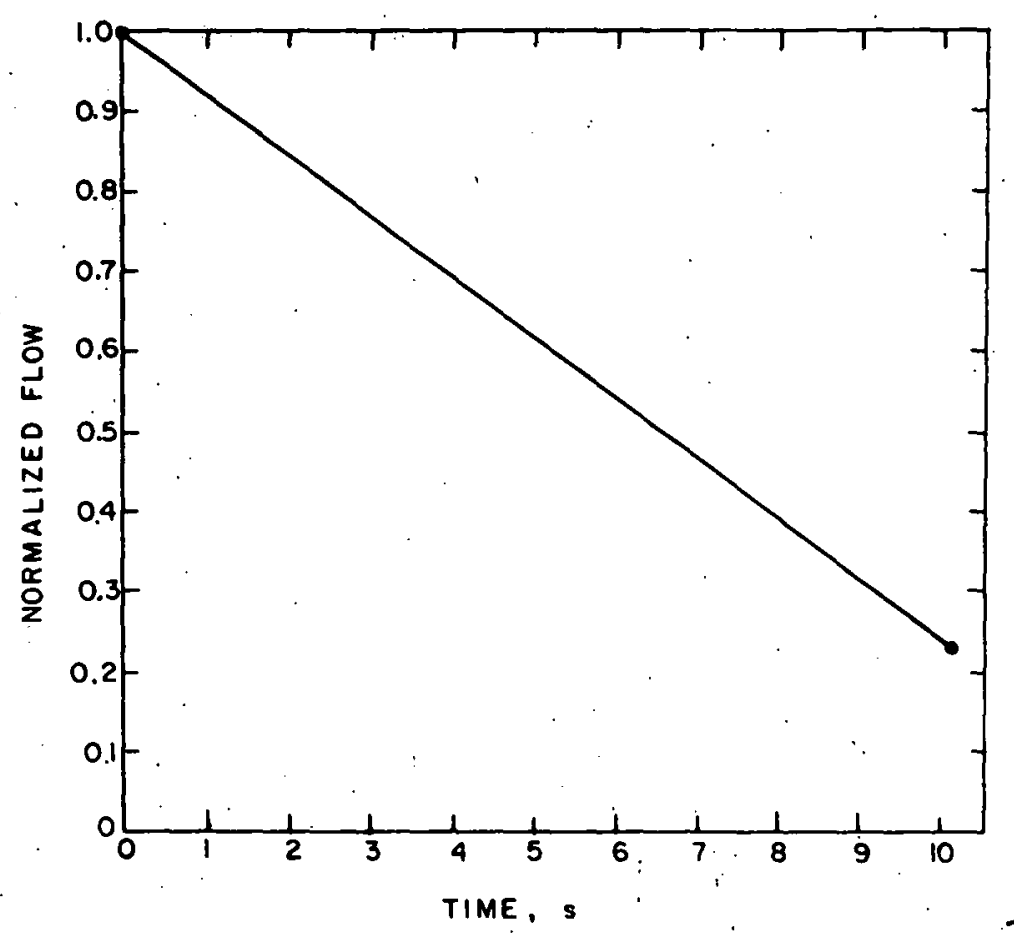

Fig. 2. Flow Rundown Transient

Fig. 3. Transient Axial Limits of Dispersed Sodium Vapor

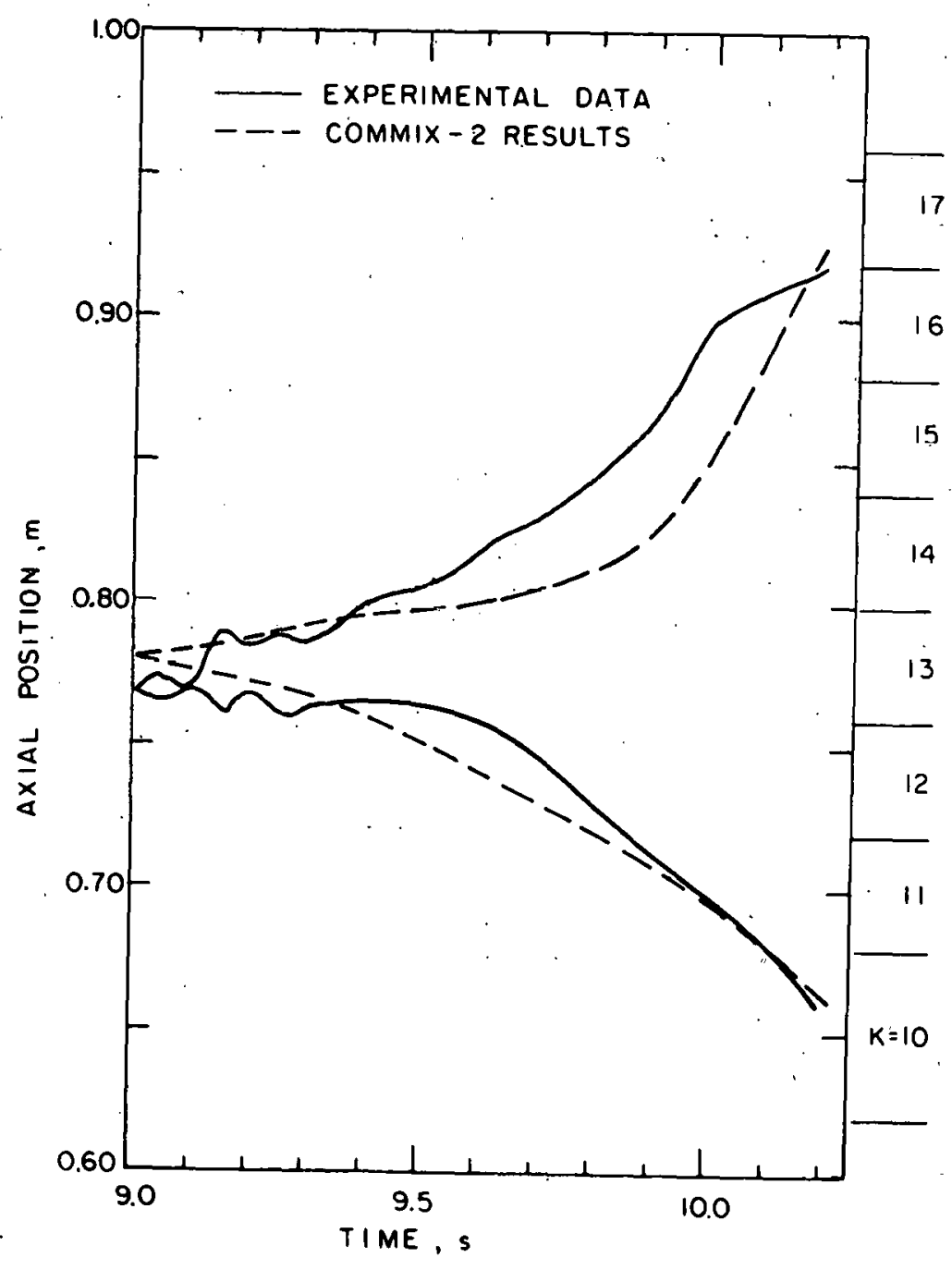


SIMULATION OF 31 PIN FUEL ASSEMBLY

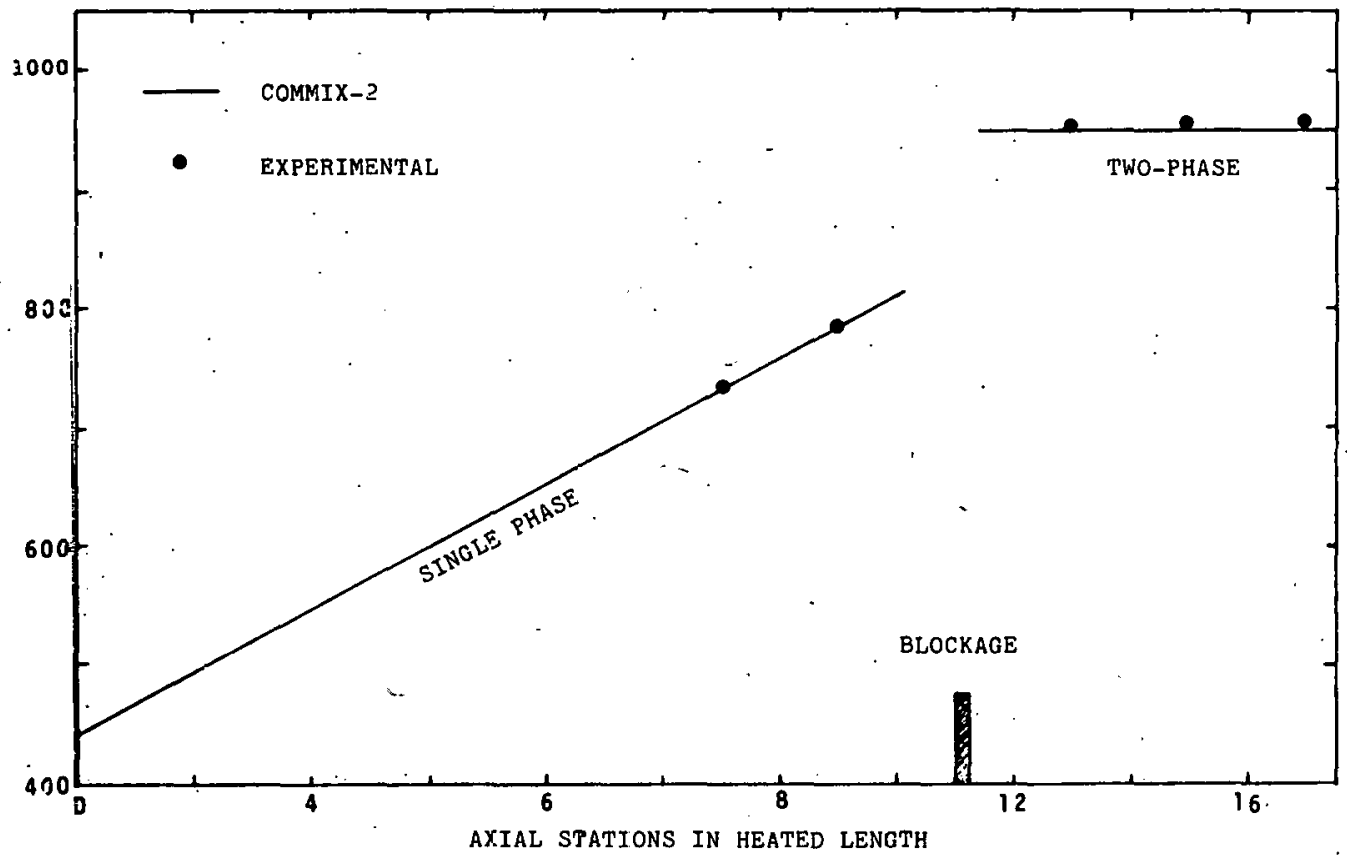

Fig. 4. Comparison of the Axial Temperature Distribution

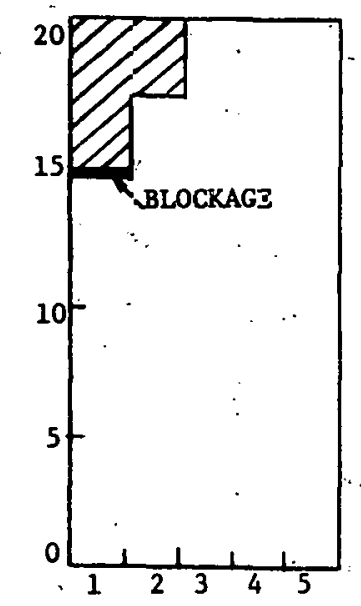

Exper1men:
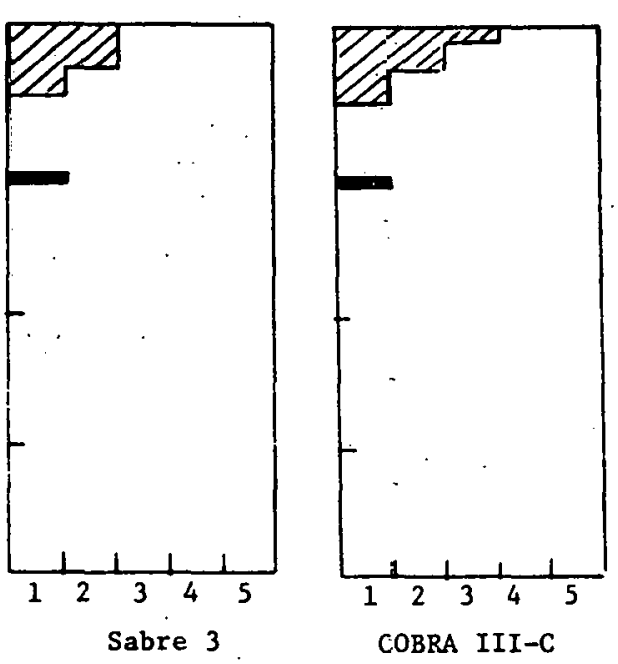
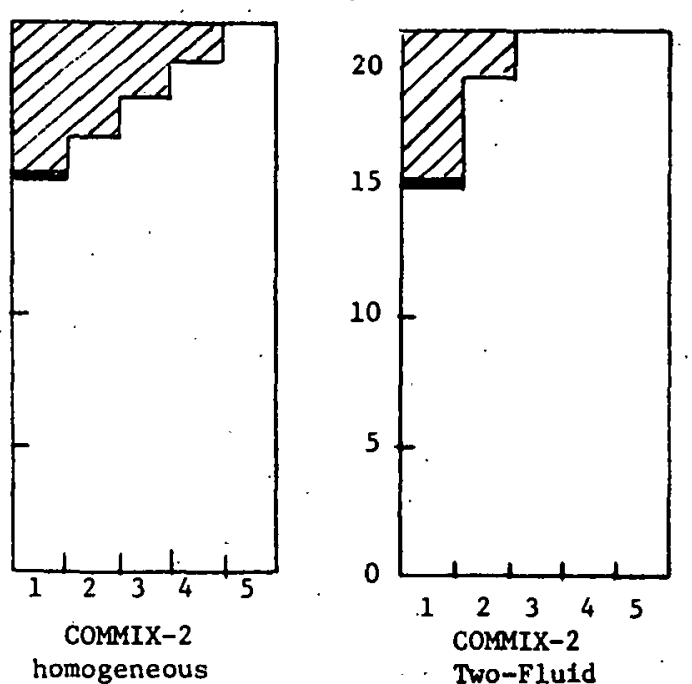

Fig. 5. Comparison of Boiling Region in THORS Bundle 3C 


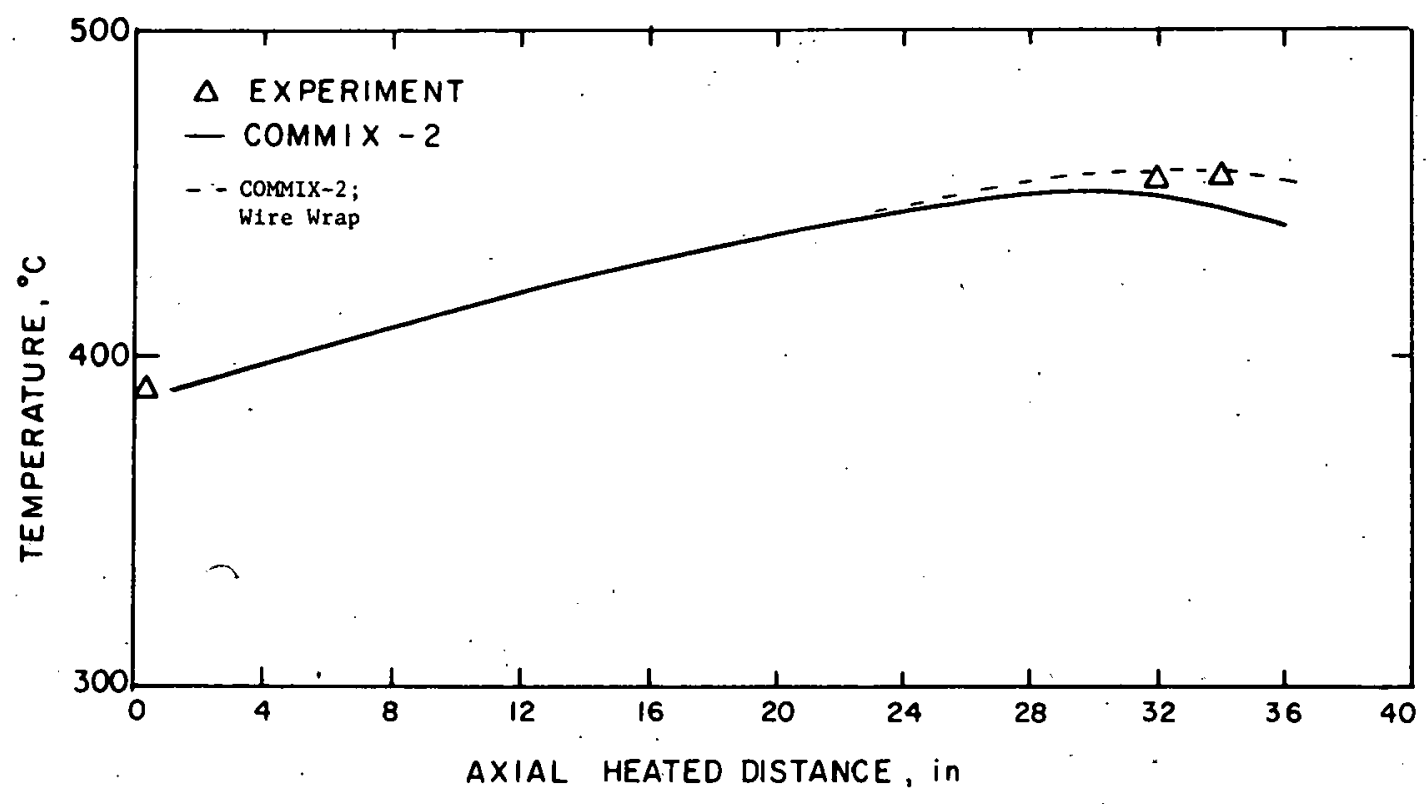

Fig. 6. Comparison of the Axial Temperature Distribution at the Center

Fig. 7. Comparison of the Radial Temperature Distribution at the End of the Heated Section

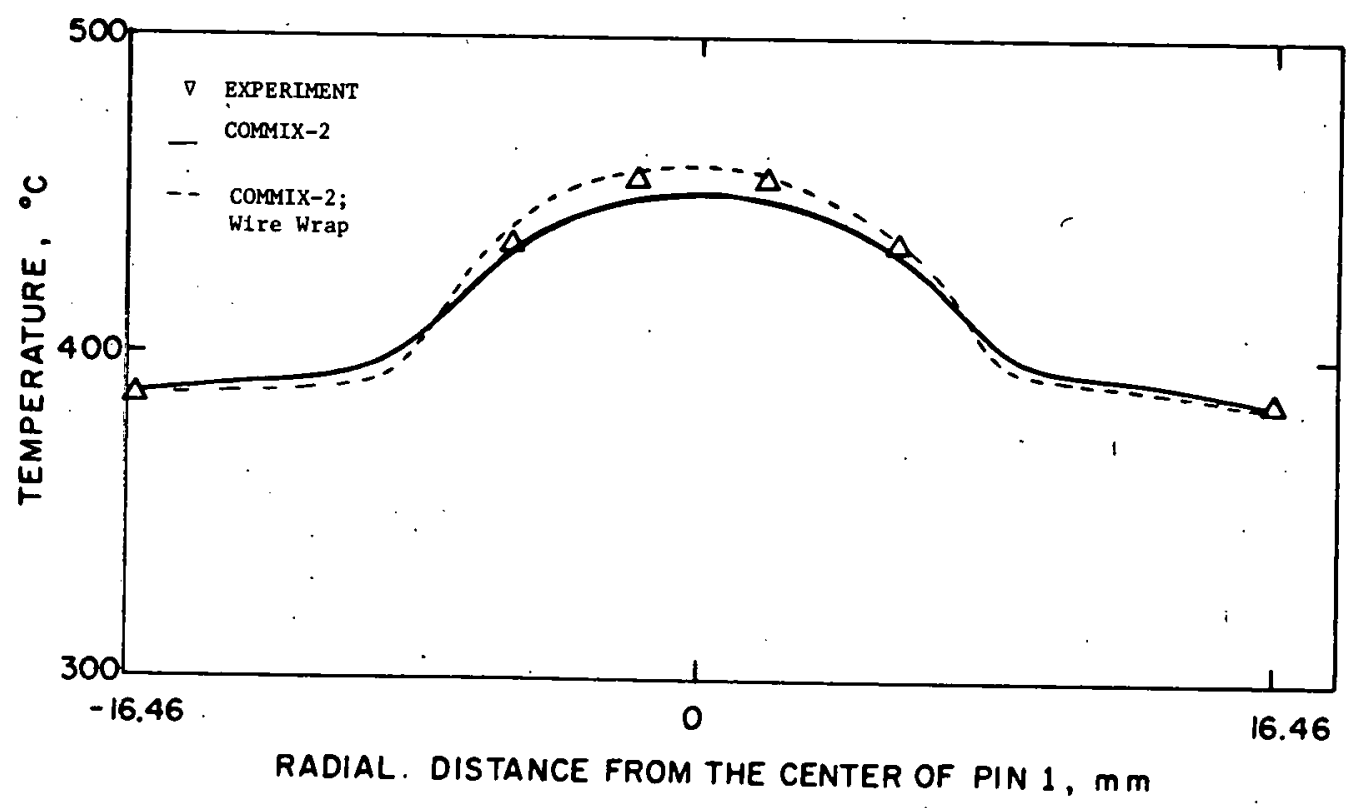




\section{REFERENCES}

1. J. L. Wantland et al., "Steady-State Sodium Tests in a 19-Pin Ful1-Length Simulated LMFBR Fuel Assembly - Record of Steady-State Experimental Data for THORS Bundle 6A," ORNL/TM-6106, Oak Ridge National Laboratory (March 1978).

2. W. T. Sha et al., "COMMIX-1; A Three-Dimensional Transient Single-Phase Component Computer Program for Thermal-Hydraulic Analysis," ANL-77-96, Argonne National Laboratory (September 1978).

3. R. J. Ribando et al., "Sodium Boiling in a Fu11-Length 19-Pin Simulated Fuel Assembly (THORS Bundle 6A)," ORNL/TM-6553, Oak Ridge National Laboratory (January 1979).

4. R. W. Ostensen, "FISGAS, A Code for Fission-Gas Migration and Fuel Swelling in an LMFBR Accident," NUREG/CR-1124, SAND 75-1-190, November 1979.

5. D. N. Worledge, "Fuel Fragmentation by Fission Gases During Rapid Heating,". NUREG/CR-1611, SAND 80-0328, June 1980.

6. J. R. Matthews and N. H. Wood, J. Nucl. Materials, 84 (1979) 125-136.

7. R. DiMe1f1, in Reactor Development Program Progress Report, February 1980, ANL-RDP-92, p. 1.15 .

8. C. Hinman and O.D . Slagle, "Ex-Reactor Transient Fission-Gas Release Studies, Fuel Pin PNL 2-4," HEDL-TME-77-83 (May 1978).

9. M. A. Perks et a1., "Comparative Analysis of a Hypothetical Transient Over Power Accident in an LMFBR Using Different Computer Models for a Common Benchmark Problem," EUR 6318 EN, 1979.

10. H. H. Hummel, in Phyșics of Reactor Safety, Quarterly Report, April-June 1975, ANL-75-67.

11. Advanced Reactor Safety Regcarch Quarterly Report, Apr11-June 197y, Sandia Laboratories, NUREG/CR-0984, SAND 79-1597, p. 58.

12. 'J. Aberle, A. J. Brook, W. Peppler, H. Rohrbacher and K. Schlelsiek, "Sodium Boiling Experiments in a 7-Pin Bundle under Flow-Rundown Conditions," KfK 2378 (November 1976).

13. H. M. Domanus, M. J. Chen and W. T. Sha, "Computational Results for a 7-Pin Hexagonal Fuel Assembly during a Flow Rundown Transient using the COMMIX-1A Computer Code," NUREG/CR-1285, ANL-CT-80-10 (January 1980). 
Distribution for NUREG/CR-1526 Vol. IV (ANL-80-54 Vol. IV)

Internal:

W. E. Massey

E. S. Beckjord

C. E. Till

J. B. Wozniak

R. Avery

P. B. Abramson

I. Bornstein/

A. B. Klickman

C. E. Dickerman

F. E. Dunn

D. Ferguson/L. Baker

S. H. Fisted is

P. L. Garner

E. Gelbard

H. Henryson
H. H. Humme 1 (7)

I. T. Hwang

Kal imull ah

M. F. Kennedy

D. H. Lennox

L. G. LeSage

P. Pizzica

F. G. Proh ammer

D. Rose/A. J. Goldman/

J. F. Marchaterre

R. Sevy

J. J. Sienicki

W. J. Sturm

B. J. Toppel
J. B. van Erp

D. Weber

H. Wider

H. M. Domanus

V. L. Shah

B. C-J. Chen

W. T. Sha

P. I. Amundson/

S. G. Carpenter

M. J. Lineberry

D. H. Shaftman

A. Trave $11 \mathrm{i}$

ANL Contract File

ANL Libraries (2)

TIS Files ( 3 )

\section{Externa1 :}

USNRC, Washington, for distribution per R7 (380)

DOE-TIC, Oak Ridge (2)

Manager, Chicago Operations and Regional Office, DOE

Chief, Office of Patent Counsel, DOE-CORO

President, Argonne Universities Association, Argonne, I11.

Applied Physics Division Review Committee:

P. W. Dickson, Jr., Clinch River Breeder Reactor Project, Oak Ridge, Tenn. 37830

R. A. Greenkorn, Purdue U., West Lafayette, Ind. 47907

R. L. Hellens, Combustion Engineering, Inc., Windsor, Conn. 06095

K. N. Tathrop. Los Alamos Scientific Lab., P. O. Box 1663, Los Alamos, N. M. 87545

W. B. Loewenstein, Electric Power Kesearch Inst., P. O. Box 10412, Palo Alto, Calif. 94303

R. Sher, St anford U., Stanford, Calif. 94305

D. B. Wehmeyer, The Detroit Edison Co., 2000 Second Ave,., Detroit, Mich. 48226

Components Technology Division Review Committee:

F. W. Buckman, Consumers Power Co., 1945 Parnall Rd., Jackson, Mich. 49201

W. M. Jacobi, Westinghouse, Pressurized Water Reactor Systems Div., Pittsburgh, Pa. 15230 .

M. A. Schultz, North Palm Beach, Fla.

J. Weisman, U. Cincinnati, Cincinnati, 0.45221

C. Erdman, U. Virginia, Charlottesville, Va. 22904

K. O. Ott, Purdue U., West Lafayette, Ind. 47906

R. Lancet, Atomics Internationa1, P. 0. Box 309, Canoga Park, Calif. 91304 
RECEIVED BK TIC MAR 201981

\section{Y $\exists \exists \wedge 00$}

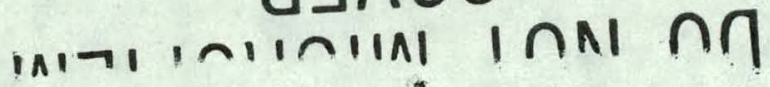

